\title{
Impacts of nano- $\mathrm{TiO}_{2}$ on the initial development stages of barley seedlings under salinity
}

\section{Nano- $\mathrm{TiO}_{2}$ 'in tuzlulukta arpa fidelerinin ilk gelişim aşamaları üzerine etkileri}

\author{
Ayşin GÜZEL DEĞER ${ }^{1}$ (iD, Sertan ÇEVIK² \\ ${ }^{1}$ Mersin University, Vocational School of Technical Sciences, Department of Food Processing, Mersin, Turkey \\ ${ }^{2}$ Vocational School of Mut, Mersin University, Mersin, Turkey \\ Corresponding author (Sorumlu yazar): A. Güzel Değer, e-mail (e-posta): agozel@mersin.edu.tr \\ Author(s) e-mail (Yazar(lar) e-posta): srtncvk@gmail.com
}

\section{ARTICLE INFO}

Received 25 October 2020

Received in revised form 05 February 2021

Accepted 08 February 2021

\section{Keywords:}

$\mathrm{NaCl}$

Nano-Priming

Germination

Relative growth index

\begin{abstract}
The most important development period in cereal plants is the initial stage, that is, seed germination and early seedling development. Even if the barley is thought to be a partially salt-tolerant plant, it may be severely affected when exposed to salinity at initial developmental periods. Pre-treatment and preparation of seeds before sowing have an important in agriculture. Nano-seed priming treatment is a new approach used to increase germination, emergence and seedling growth recently. In this study, the effects of nano- $\mathrm{TiO}_{2}$ $\left(0,100,200 \mathrm{mg} \mathrm{L}^{-1} \mathrm{n}-\mathrm{TiO}_{2}\right)$ pre-application and ongoing/combination application under salinity $(0,100,200,300 \mathrm{mM} \mathrm{NaCl})$ on germination and early seedling growth of barley plants were investigated. Root lengths (RL, $\mathrm{mm}$ ), germination rates (GR, \%), radicle emerging (RE, \%), number of coleoptiles (CN) were measured depending on the day $(1,2,3$ days). At the end of the third day, seedling fresh and dry weights (FW,DW mg) were measured. The relative growth index (RGI) of root and mean germination time (MGT) were calculated. It was determined that the application of $100 \mathrm{mg} \mathrm{L}^{-1} \mathrm{n}-\mathrm{TiO}_{2}$ increased root length and RGI compared to control groups. It was observed that the application of $100 \mathrm{mg} \mathrm{L}^{-1} \mathrm{n}-\mathrm{TiO}_{2}$ significantly increased the germination percentage, biomass and root length especially in $100 \mathrm{mM}$ salt conditions. Also, $100 \mathrm{mg} \mathrm{L}^{-1} \mathrm{n}-\mathrm{TiO}_{2}$ increased the $\mathrm{RE}$ too in $100 \mathrm{mM}$ salt conditions (1st day). In this study, it was determined that $300 \mathrm{mM} \mathrm{NaCl}$ was inhibitory dose, and also germination remained below $20 \%$ in $200 \mathrm{mM} \mathrm{NaCl}$ in all groups.
\end{abstract}

\section{MAKALE BILGISI}

Alınıs tarihi 25 Ekim 2020

Düzeltilme tarihi 05 Şubat 2021

Kabul tarihi 08 Şubat 2021

\section{Anahtar Kelimeler:}

$\mathrm{NaCl}$

Nano-hazırlama

Çimlenme

Göreceli büyüme endeksi

\section{ÖZ}

Tahıl bitkilerindeki en önemli dönem, başlangıç aşaması, yani tohum çimlenmesi ve erken fide gelişimidir. Arpanın kısmen tuza toleranslı olduğu düşünülse bile, belirli gelişim dönemlerinde tuzluluğa maruz kaldığında ciddi şekilde etkilenebilir. Ekim öncesi tohumların ön işlemden geçirilmesi ve hazırlanması tarımda önemli bir yere sahiptir. Nano-tohum hazırlama uygulaması son zamanlarda çimlenme, ortaya çıkış ve fide büyümesini arttırmak için kullanılan yeni bir yaklaşımdır. Bu nedenle, bu araştırmada, tuzluluk durumunda $(0,100,200$, $300 \mathrm{mM} \mathrm{NaCl})$ nano- $\mathrm{TiO}_{2}\left(0,100,200 \mathrm{mg} \mathrm{L}^{-1} \mathrm{TiO}_{2}\right)$ ön uygulaması ve devam eden/kombinasyon uygulamalar ile çimlenme ve erken fide büyümesi üzerindeki etkilerini araştıran bir çalışma tasarlanmıştır. Çalışmada güne bağlı olarak kök uzunlukları (mm), çimlenme oranları (\%), radikula çıkışı (\%) koleoptil sayısı ölçüldü $(1,2,3$. gün). Üçüncü günün sonunda taze ve kuru ağırlık (mg) belirlendi. Kökün bağıl büyüme indeksi ve ortalama çimlenme süresi hesaplandı. $100 \mathrm{mg} \mathrm{L}^{-1} \mathrm{n}-\mathrm{TiO}_{2}$ uygulamasının kontrol gruplarına kıyasla kök uzunluğunu ve kökün bağıl büyüme indeksini arttırdığı belirlenmiştir. $100 \mathrm{mg} \mathrm{L}^{-1} \mathrm{n}-\mathrm{TiO}_{2}$ uygulamasının çimlenme yüzdesini, biyokütleyi ve kök uzunluğunu özellikle $100 \mathrm{mM}$ tuz koşullarında önemli ölçüde arttırdığı gözlenmiştir. Ayrıca, $100 \mathrm{mg} \mathrm{L}^{-1} \mathrm{n}-\mathrm{TiO}_{2}, 100 \mathrm{mM}$ tuz koşullarında (1. gün) radikula çıkışını da artırıdı. Bu çalışmada, $300 \mathrm{mM} \mathrm{NaCl'nin} \mathrm{inhibitör}$ doz olduğu ve ayrıca çimlenmenin $200 \mathrm{mM} \mathrm{NaCl}$ içinde tüm gruplarda \%20'nin altında kaldığı belirlenmiştir. 


\section{Introduction}

Cereal seeds cultivated in the field are exposed to severe environmental stress factors, especially during early germination, emergence and beginning seedling development (Bennett et al. 1992). Aridity and saltiness come first among these undesirable environmental stress conditions (Panuccio et al. 2014). Barley (Hordeum vulgare L.), is a wanted cereal crop cultivated in very large areas in Turkey and in the world. Barley is considered a partially salt-tolerant cereal crop and it was reported that the "Kral 97" genotype used in this study was of moderate tolerance (Bağc1 et al. 2003; Mahmood 2011).

Pre-treatment and preparation of seeds before sowing in order to improve quality and increase germination energy in agricultural production has been an application area that has been ongoing for a long time and has been popular recently. This method of application may mostly use to increase the germination rate, total germination and seedling power under unfavorable environmental conditions. This technique, called seed priming, which is used especially for cereal and vegetable seeds, stimulates metabolic processes related to seed germination and early seedling development, and as an outcome of these processes, seeds resistant to abiotic stress conditions, like water scarcity develop (Korkmaz and Pill 2003; Armin et al. 2010; Theerakulpisut et al. 2016).

A wide variety of seed priming agents can be used to increase the effectiveness of seeds and reduce the impact of environmental stresses. These seed priming agents may have osmo-, hydro-,chem-, bio-, hormo-, halo-priming properties. New priming materials have been added to the existing seed priming agents with the developing technologies (such as nanotechnology) recently. Nano-seed priming treatment is a new approach used to increase germination, emergence and seedling growth. (Lutts et al. 2016; Mahakham et al. 2017; Acharya et al. 2020). Metallic nanoparticles (zinc, titanium, and silver) can be used as protective agents against biotic and abiotic stress factors (do Espirito Santo Pereira et al. 2021).

$\mathrm{TiO}_{2}$ nanoparticles (NPs) occur in 3 different forms as anatase, rutile and brookite (Macwan et al. 2011). $\mathrm{TiO}_{2}$ nanoparticles have been one of the 10 most used nanoparticle types in the world and it has a wide range of usage in different sectors from cosmetics to batteries, paint to construction industry and from the food industry to the pharmaceutical industry (Piccinno et al. 2012; Gogos et al. 2012, Liu and Cohen 2014). In addition to, $\mathrm{TiO}_{2}$ nanoparticle is included in the list of nanoparticles that should be examined primarily by the Organization for Economic Development and Cooperation (OECD 2010).

Titanium is also a quite widely used chemical element in agricultural research. Although titanium is not included in the essential list of macro and microelements among plant nutrients, it has been widely used in plant nutrition lately (Bacilieri et al. 2017) and farther it is thought to be a benefical element when used correctly in crop production (Lyu et al. 2017). There are many studies reporting that this element has a positive effect on plants under stress conditions, especially germination, root development and vegetative growth (Feizi et al. 2012; Dehkourdi and Mosavi 2013; Haghighi and Silva 2014; Mutlu et al. 2018).

Overall, researchers suggest that the application of $\mathrm{TiO}_{2}$ NPs in salt stress, drought stress, and heavy metal stress situations can be a promising approach to prevent their negative effects on seed germination and early growth. There is a huge gap still waiting to be investigated regarding the use of nanoparticles in seed preparation. In this study, it has been tried to find answers to the question of whether nano- $\mathrm{TiO}_{2}$ be one of these new priming agents? The application time of the nanoparticles, the way of application, the concentration to be applied, and how it will be applied in which stress situation, how it will work, is a highly interesting subject. Therefore, in this research, a study that investigates the effects on germination rate, root length, biomass and coleoptile with $\mathrm{TiO}_{2}$ nanoparticle pre-application and ongoing application under salt stress is designed.

\section{Materials and Methods}

\subsection{Seed samples}

The seeds of Hordeum vulgare L. (barley), which are widely cultivated, were used in this study. Barley seeds were subjected to surface sterilization prior put to use. After the seeds were kept in 5\% sodium hypochlorite for 5 minutes, they were washed five times with pure water and dried at room temperature on filter papers and used in the study.

\subsection{Preparation and pre-application of $\mathrm{TiO}_{2}$ nanoparticle suspensions}

The commercial form of $\mathrm{TiO}_{2}$ nanoparticles $(32 \mathrm{~nm})$ was used in the study (Titanium (IV) oxide, NanoArc, anatase, nanopowder, $99.9 \%$ metals basis). Suspensions of $\mathrm{TiO}_{2} \mathrm{NPs}$ were freshly prepared by dissolving directly in deionized water and dispersed by ultrasonic vibration for $30 \mathrm{~min}(100 \mathrm{~W}, 40$ $\mathrm{KHz}$ ). The suspensions were stirred before use to avoid the aggregation of nanoparticles (Garcia-Lopez et al. 2018). Surface sterilized seeds were kept in aerated solution containing different concentrations of nano- $\mathrm{TiO}_{2}\left(0,100,200 \mathrm{mg} \mathrm{L}^{-1} \mathrm{TiO}_{2}\right)$ for $24 \mathrm{~h}$ before salinity application. At the end of this pretreatment, seeds for each application were put between two layers of filter papers in square petri dishes. 25 seeds were placed in each petri dish and the study was carried out with 4 repetitions.

\section{3. $\mathrm{TiO}_{2}$ nanoparticle and salinity applications}

Nanoparticle applications were made as pre-applications before switching to salt and nanoparticle combined applications. Solutions containing nanoparticle $\left(0,100,200 \mathrm{mg} \mathrm{L}^{-1} \mathrm{TiO}_{2}\right)$ and salt $(0,100,200,300 \mathrm{mM} \mathrm{NaCl})$ in different concentrations were added in equal amounts on the seeds found in petri dishes in the combinations given in Table 1. The same amount of deionized water was added to the control groups. There were 12 application groups in total and 100 seeds were used in each application group (Table 1).

\subsection{Germination of barley seeds and growth}

The application groups in petri dishes were germinated at 24:18 ${ }^{\circ} \mathrm{C}$ day:night temperature, 16:8 day:night light period, 150 $\mu \mathrm{mol} \mathrm{m} \mathrm{m}^{-2} \mathrm{~s}^{-1}$ light intensity and $60 \pm 5 \%$ humidity conditions for 3 days under controlled conditions in the climate room.

\subsection{Assays}

In the study, root lengths (RL, mm), germination rates (\%), radicle emerging (RE, \%), number of coleoptiles $(\mathrm{CN})$ were measured depending on the day (1, 2, 3 days). At the end of the third day, seed fresh and dry weight $\left(\right.$ at $80^{\circ} \mathrm{C}$ for $\left.24 \mathrm{~h}\right)(\mathrm{mg})$ were measured. Seed weights were given for 100 seeds. In 
Table 1. Experimental application groups.

\begin{tabular}{|c|c|c|}
\hline Groups & $\mathrm{NaCl}(\mathrm{mM})$ & TiO2 $\left(\mathrm{mg} \mathrm{L}^{-1}\right)$ \\
\hline 1 & 0 & 0 \\
\hline 2 & 0 & 100 \\
\hline 3 & 0 & 200 \\
\hline 4 & 100 & 0 \\
\hline 5 & 100 & 100 \\
\hline 6 & 100 & 200 \\
\hline 7 & 200 & 0 \\
\hline 8 & 200 & 100 \\
\hline 9 & 200 & 200 \\
\hline 10 & 300 & 0 \\
\hline 11 & 300 & 100 \\
\hline 12 & 300 & 200 \\
\hline
\end{tabular}

addition, plants were photographed daily for three days. The relative growth index (RGI) of root and mean germination time (MGT) were calculated.

Seeds were considered germinated when the radicles were $\geq 2 \mathrm{~mm}$ long and radicle emergence was defined as the radicles were <2 mm long (Kaya et al. 2006; Gao et al. 2018). The number of seeds that emerged and germinated was recorded every $24 \mathrm{~h}$ for 3 days. Radicle emergence and seed germination percentages were calculated using the following formulas (Koksal et al. 2015; Gao et al. 2018).

Radicle Emergence $(\%)=$ Number of emerged seeds $/$ Total number of seeds $X 100$

Seed Germination $(\%)=$ Number of germinated seeds / Total number of seeds $X 100$

Root length was measured daily with digital caliper. Based on the daily measurement relative growth index (RGI) of root was calculated with following formula:

$$
R G I(m m \quad \text { day } ₫ \wedge(-1))=(R L 2-R L 1) /(t 2-t 1)
$$

The RGI formula was modified from Acosta-Motos et al. (2017) and Ren et al. (2016).

Where, RL2 - RL1, root length for seed at the beginning and at the end of experiment; $\mathrm{t} 2-\mathrm{t} 1$ was the time duration for the treatment.

\subsection{Statistical analysis}

The experiment was conducted using a completely randomized experimental design with two factors $(\mathrm{NaCl}$ and $\mathrm{n}-\mathrm{TiO}_{2}$ concentrations). Treatments had four replications with 25 seeds each. All quantitative data expressed as percentages were subjected to arcsine transformation. Data were subjected to ANOVA and the means were separated using the LSD multiple range test at $\mathrm{p} \leq 0.05$. All statistical analyses were performed using the JMP8 software package.

\section{Results and Discussion}

This study was carried out to evaluate the effects of nanoparticles and salinity at the initial stage of plant development in nano $\mathrm{TiO}_{2}$-primed barley seeds. Different concentrations of primed nano- $\mathrm{TiO}_{2}\left(0,100,200 \mathrm{mg} \mathrm{L}^{-1} \mathrm{TiO}_{2}\right)$ seeds were germinated under different concentrations of $\mathrm{NaCl}$ $(0,100,200$ and $300 \mathrm{mM})$, nano- $\mathrm{TiO}_{2}\left(0,100,200 \mathrm{mg} \mathrm{L}^{-1} \mathrm{TiO}_{2}\right)$ and $\mathrm{NaCl} / \mathrm{n}-\mathrm{TiO}_{2}$ combinations. The effects of Nano-seed priming, nanoparticles and salt applications on the root lengths, germination rates, coleoptile and biomass were comparatively investigated daily for 3 days. In addition, RGI and MGT were calculated based on with these data. Phenotypic images of barley seedlings in different concentrations of $\mathrm{TiO}_{2} \mathrm{NPs} / \mathrm{NaCl}$ treatments depending on the days are given in Figure 1 (a, b, c). The effects of nano-titanium and salinity were found significant in terms of germination and early seedling parameters on barley plants, statistically.

The findings in this study showed that the germination and growth parameters of barley were negatively affected due to the increased salt concentration (Figure 1a, b, c). In many studies, including this study, salinity in barley plants has been shown to reduce seed germination, radicle emergence and inhibit root elongation depending on the concentration (Ayers 1953; Bağc1 et al. 2003; Katerji et al. 2006; Mahmood 2011; Askari et al. 2016; Demiroğlu Topçu and Özkan 2017). Germination times were lengthen out as the salt concentration increased. It was found that germination did not occur at a salt concentration of $300 \mathrm{mM}$, indicating that this concentration was an overly high dose for the "Barley Kral 97". So what differences have been observed with the application of titanium nanoparticles?

Strikingly, on the first day of application (Figure 1a), the highest RE (20\%) ratio was obtained at $100 \mathrm{mg} \mathrm{L}^{-1}$ nano- $\mathrm{TiO}_{2}+100 \mathrm{mM}$ salt application compared to all groups. This rise was exactly twice of $100 \mathrm{mM}$ salt applications (\%10) (Figure 2a). It was observed that germination rates dramatically decreased significantly with the increase in salinity (Figure 2b). On the 3rd day of treatment (Figure 1c), the highest values of germination rates were obtained from control $(87 \%)$ and 100 $\mathrm{mg} \mathrm{L}^{-1}$ nano- $\mathrm{TiO}_{2}(83 \%)$. When the salt concentration was 100 $\mathrm{mM}$, the highest germination rates were found in $100 \mathrm{mg} \mathrm{L}^{-1}$ nano- $\mathrm{TiO}_{2}(70 \%)$ (Table 2). The protective effect of $\mathrm{TiO}_{2}$ was seen when the salinity level was $100 \mathrm{mM}$.

As seen in Figure 2c, when salinity and $\mathrm{TiO}_{2}$ levels increased, coleoptile numbers drastically decreased (Table 2). The highest values of coleoptile numbers were obtained from control $(78 \%)$ and $100 \mathrm{mg} \mathrm{L}^{-1}$ nano- $\mathrm{TiO}_{2}(76 \%)$. Coleoptile numbers decreased at $200 \mathrm{mg} \mathrm{L}^{-1}$ nano- $\mathrm{TiO}_{2}$ (59\%). Titanium could not positively effective of coleoptile numbers under saline conditions (Table 3).

Treatment effects in terms of root length on daily observations were shown in Figure 3. The effects of salinity and nano- $\mathrm{TiO}_{2}$ on root length were presented in Tables 2 and 3 . When salinity increased, root length dramatically decreased. The highest values of root length were obtained from control $(16.69 \mathrm{~mm})$ and $100 \mathrm{mg} \mathrm{L}^{-1} \mathrm{Nano}^{-\mathrm{TiO}_{2}}(17.6 \mathrm{~mm})$. Root length decreased at $200 \mathrm{mg} \mathrm{L}^{-1}$ nano- $\mathrm{TiO}_{2}(11.0 \mathrm{~mm})$. Although there were no statistical differences among control and $100 \mathrm{mg} \mathrm{L}^{-1}$ nano- $\mathrm{TiO}_{2}$ in terms of root length, the highest root length values were obtained $100 \mathrm{mg} \mathrm{L}^{-1}$ nano- $\mathrm{TiO}_{2}$ levels $(5.75 \mathrm{~mm})$. When the salt concentration was $100 \mathrm{mM}$, the most root length was found in the plants treated with $100 \mathrm{mg} \mathrm{L}^{-1}$ nano- $\mathrm{TiO}_{2}$ levels $(4.99 \mathrm{~mm})$. When the salt level was up to $100 \mathrm{mM}$, root length decreased, drastically (Table 3).

The effects of salinity and titanium on the fresh weight (FW) of seeds were presented in Tables 2 and 3. As salinity increased, fresh weight decreased. The differences between fresh weights in terms of salt treatments were found important, statistically. Nano- $\mathrm{TiO}_{2}$ did not affect the fresh weights of plants (Table 2). It was not seen statistically significant differences in 
terms of barley seeds dry weights (DW) under salinity and titanium treatments (Tables 2 and 3).

The root relative growth index (RGI) results clearly demonstrated the negative effects of salt stress on the radicle development stage of the seeds (Table 2). The highest RGI was obtained from control (7.37) and $100 \mathrm{mg} \mathrm{L}^{-1}$ nano- $\mathrm{TiO}_{2}$ (7.68). The mean germination time (MGT) increased with $200 \mathrm{mM}$ $\mathrm{NaCI}+\mathrm{n}-\mathrm{TiO}_{2}$ application.

Gohari et al. (2000) showed that 50 and $100 \mathrm{mM} \mathrm{NaCl}$ negatively affect the agronomic properties (plant height, shoot and leaf fresh and dry weights and leaf number) of the Dracocephalum moldavica, but the application of $100 \mathrm{mg} \mathrm{L}^{-1}$ $\mathrm{TiO}_{2}$ NPs reduces these negative effects, as in the results of this study. Also, Feizi et al. (2012) reported that nano- $\mathrm{TiO}_{2}$ in a suitable concentration could promote the seed germination of wheat in comparison to bulk $\mathrm{TiO}_{2}$. Haghighi and Silva (2014) reported that nano- $\mathrm{TiO}_{2}$ application had a positive effects on germination studies on tomato, onion and radish seeds that 200 , 100 and less than $100 \mathrm{mg} \mathrm{L}^{-1} \mathrm{TiO}_{2}$, respectively, were appropriate concentrations and suggested that nano- $\mathrm{TiO}_{2}$ may function as a seed priming agent for horticultural crops. However, they especially emphasized in their studies that need for more experiments should be done on this subject. Dehkourdi and Mosavi (2013) showed that the application of nano-anatase $\mathrm{TiO}_{2}$ at a concentration of $30 \mathrm{mg} \mathrm{ml}^{-1}$ caused a significant increase in germination, germination rate index, root and shoot length, fresh weight, viability index and chlorophyll content. Mutlu et al. (2018) reported that nano- $\mathrm{TiO}_{2}$ treatments $(0.1 \%$, $0.2 \%$ and $0.3 \%$ ) were ineffective on germination percentage in maize cultivar, regardless of concentration. In the case of stress $(300 \mathrm{mM} \mathrm{NaCl})$, they indicated that nano- $\mathrm{TiO}_{2}$ treatments caused significant increases in root-stem length and fresh-dry weights. Further, notified that the application of salt stress in maize plants inhibits seed germination and seedling growth. Doğaroğlu and Köleli (2016) reported that especially in 80 and $100 \mathrm{mg} \mathrm{L}^{-1}$ nano-TiO 2 concentration, number of seed germination increased compared to control in lettuce. Younes et al. (2020) pointed out the extraordinary effect on germination characteristics and seedling growth by treating seeds of eggplant, pepper and tomato plants with gel-coated $\mathrm{TiO}_{2}$ nanomaterials $\left(0,50,100\right.$ and $\left.150 \mathrm{mg} \mathrm{L}^{-1}\right)$. They reported that the maximum transplants lengths, fresh and dry weight were recorded at the level $100 \mathrm{mg} \mathrm{L}^{-1}$ nano- $\mathrm{TiO}_{2}$ whatever the crop plant used, in line with the results in this study. Also, in the same study it has been shown that in the solanaceae family that the germinability increased and the mean germination time decreased by gel-coating the seeds with $100 \mathrm{mg} \mathrm{L}^{-1}$ nano- $\mathrm{TiO}_{2}$ (Younes et al. 2020). Besides, It has been suggested that different nanoparticle seed preparation practices under salt stress in cotton and cucumber seeds are a sustainable, practical and scalable tool to improve crop tolerance to stress (An et al. 2020; Mahdy et al. 2020). As seen in the studies, there are differences in the response to nanoparticles between concentration, application method and plant types.

Taken together all of these literature, similar results also reported by other researchers on the different plant species To summarize the study, it was observed that $100 \mathrm{mg} \mathrm{L}^{-1}$ nano- $\mathrm{TiO}_{2}$ application increased root length and RGI compared to control groups. It was determined that $100 \mathrm{mg} \mathrm{L}^{-1}$ nano- $\mathrm{TiO}_{2}$ application significantly increased RE, germination percentage, biomass and root length, especially under $100 \mathrm{mM}$ salt conditions.
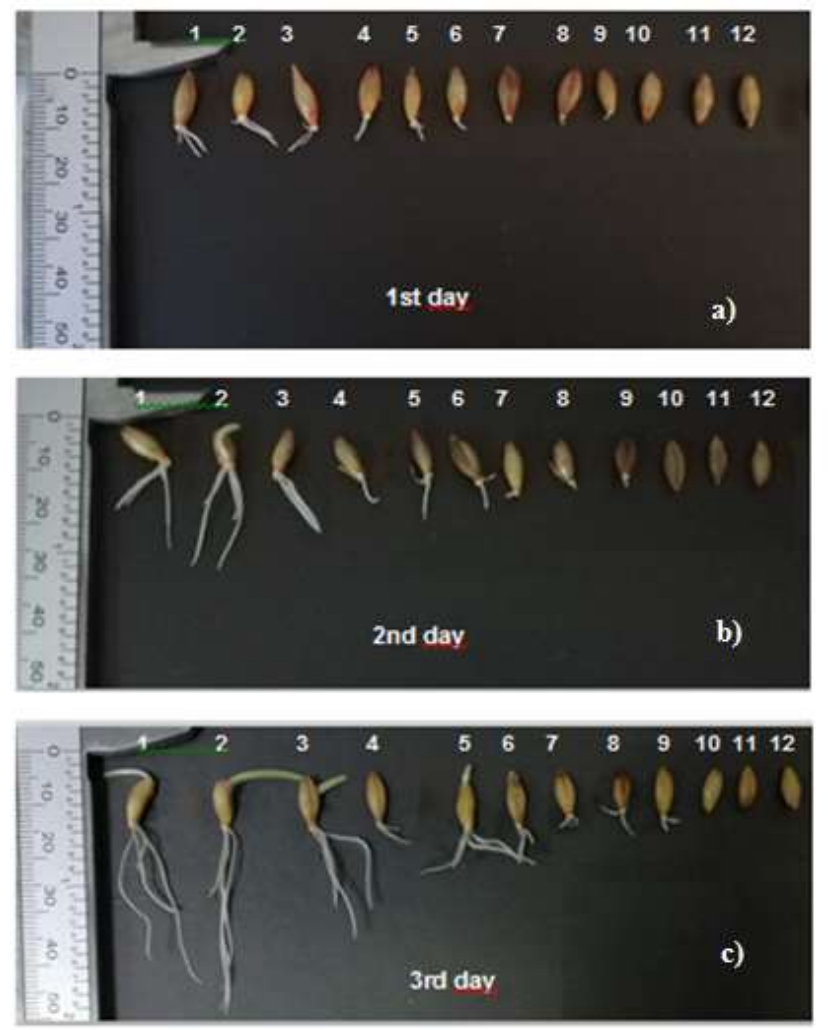

Figure 1. Phenotypic images of barley seedlings in different concentrations of $\mathrm{TiO}_{2} \mathrm{NPs} / \mathrm{NaCl}$ treatments depending on the days [a) $1 \mathrm{st}$ day, b) $2 \mathrm{nd}$ day, c) 3rd day]. 

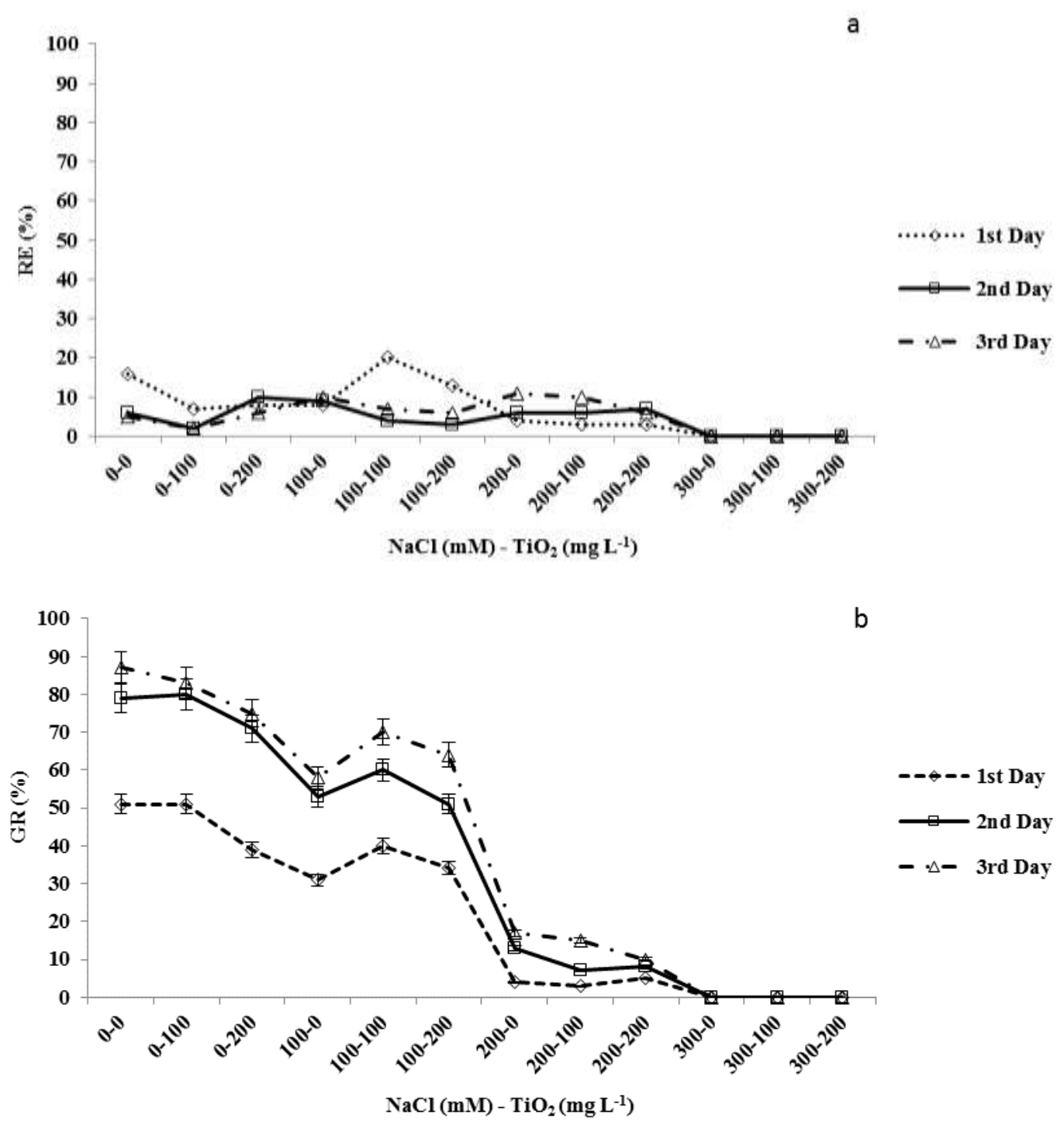

b

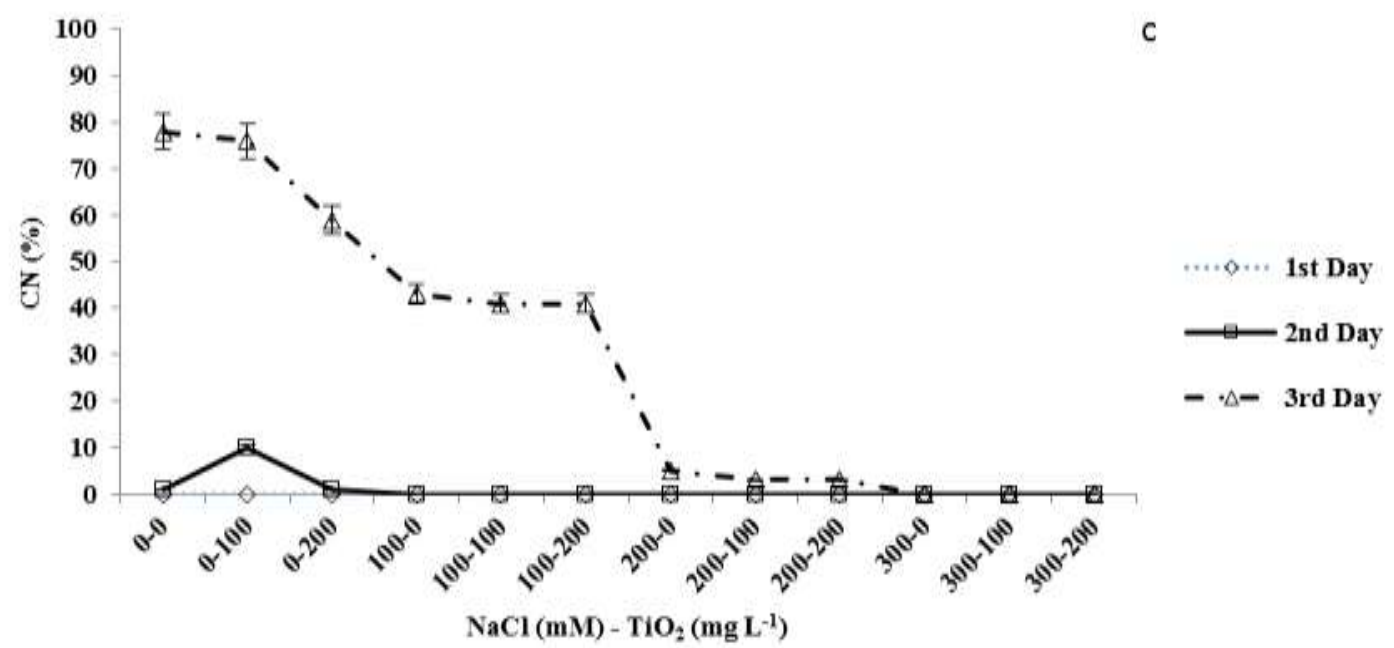

Figure 2. a) Radicle emergence percentage (RE-\%), b) Germination percentage (GR-\%), c) Coleoptile number (CN-\%) of barley seedlings in different concentrations of $\mathrm{TiO}_{2} \mathrm{NPs} / \mathrm{NaCl}$ treatments, depending on the days. 
Table 2. Effects of $n-\mathrm{TiO}_{2}$ and salinity interactions on MGT, RE, GR, CN, RL, FW, DW, RGI on thr 3rd day.

\begin{tabular}{|c|c|c|c|c|c|c|c|c|c|}
\hline $\begin{array}{l}\text { Salinity } \\
(\mathrm{mM})\end{array}$ & $\begin{array}{c}\mathrm{n}-\mathrm{TiO}_{2} \\
\left(\mathrm{mg} \mathrm{L} \mathbf{L}^{-1}\right)\end{array}$ & $\begin{array}{c}\text { Mean Germination } \\
\text { Time }\end{array}$ & $\begin{array}{c}\text { Radicle } \\
\text { Emerging }(\%)\end{array}$ & $\begin{array}{c}\text { Germination } \\
\text { rate }(\%)\end{array}$ & $\begin{array}{c}\text { Coleoptile } \\
\text { number }(\%)\end{array}$ & $\begin{array}{c}\text { Root length } \\
(\mathrm{mm})\end{array}$ & $\begin{array}{c}\text { Fresh } \\
\text { Weight (g) }\end{array}$ & $\begin{array}{c}\text { Dry } \\
\text { Weight (g) }\end{array}$ & $\begin{array}{c}\text { RGI } \\
\text { mm day }^{-1}\end{array}$ \\
\hline \multirow{3}{*}{$\mathbf{0}$} & 0 & $1.48 \mathrm{c}$ & $5(12) c$ & $87(69) a$ & $78(62) \mathrm{a}$ & $16.69 a$ & 2.90 & 1.05 & $7.37 \mathrm{a}$ \\
\hline & 100 & $1.42 \mathrm{c}$ & $2(7) d$ & $83(66) a$ & $76(61) \mathrm{a}$ & $17.6 \mathrm{a}$ & 2.95 & 1.05 & $7.68 \mathrm{a}$ \\
\hline & 200 & $1.53 \mathrm{c}$ & $6(14) \mathrm{c}$ & $75(60) \mathrm{b}$ & $59(50) \mathrm{c}$ & $11.0 \mathrm{~b}$ & 2.55 & 1.06 & $4.83 \mathrm{~b}$ \\
\hline \multirow{3}{*}{100} & $\mathbf{0}$ & $1.55 \mathrm{c}$ & $10(18) \mathrm{ab}$ & $58(50) \mathrm{d}$ & $43(41) c$ & $3.80 \mathrm{c}$ & 2.31 & 1.16 & $1.56 \mathrm{c}$ \\
\hline & 100 & $1.57 \mathrm{c}$ & $7(15) b c$ & $70(57) \mathrm{bc}$ & $41(40) \mathrm{c}$ & $4.99 c$ & 2.21 & 1.11 & $2.12 \mathrm{c}$ \\
\hline & 200 & $1.67 \mathrm{c}$ & $6(14) c$ & $64(53) \mathrm{cd}$ & $41(40) \mathrm{c}$ & $3.92 \mathrm{c}$ & 2.14 & 1.10 & $1.65 \mathrm{c}$ \\
\hline \multirow{3}{*}{200} & 0 & $1.96 \mathrm{~b}$ & $11(20) \mathrm{a}$ & $17(24) \mathrm{e}$ & $5(12) d$ & $0.45 \mathrm{~d}$ & 1.93 & 1.10 & $0.22 \mathrm{~d}$ \\
\hline & 100 & $2.33 \mathrm{a}$ & $10(18) \mathrm{ab}$ & $15(23) \mathrm{e}$ & $3(10) \mathrm{e}$ & $0.42 \mathrm{~d}$ & 1.89 & 1.09 & $0.20 \mathrm{~d}$ \\
\hline & 200 & $1.63 \mathrm{c}$ & $6(14) c$ & $10(18) \mathrm{f}$ & $3(10) \mathrm{e}$ & $0.26 \mathrm{~d}$ & 1.96 & 1.13 & $0.12 \mathrm{~d}$ \\
\hline \multirow{3}{*}{300} & $\mathbf{0}$ & $0 \mathrm{~d}$ & $0 \mathrm{e}$ & $0 \mathrm{~g}$ & Of & $0 \mathrm{~d}$ & 1.86 & 1.13 & Od \\
\hline & 100 & $0 \mathrm{~d}$ & $0 \mathrm{e}$ & $0 \mathrm{~g}$ & Of & Od & 1.91 & 1.16 & $0 \mathrm{~d}$ \\
\hline & 200 & $0 \mathrm{~d}$ & $0 \mathrm{e}$ & $0 \mathrm{~g}$ & Of & $0 \mathrm{~d}$ & 1.77 & 1.16 & $0 \mathrm{~d}$ \\
\hline \multicolumn{2}{|c|}{$L S D$} & $0.261 * *$ & $3.609 * *$ & $3.856^{* * *}$ & $2.552 * * *$ & $2.080 * * *$ & $-{ }_{--}^{N S}$ & $-{ }_{--}^{N S}$ & $0.980^{* * *}$ \\
\hline
\end{tabular}

Table 3. Effects of $n-\mathrm{TiO}_{2}$ and salinity levels on MGT, RE, GR, CN, RL, FW, DW, RGI on thr 3rd day.

\begin{tabular}{|c|c|c|c|c|c|c|c|c|}
\hline $\mathrm{NaCl}(\mathrm{mM})$ & MGT & $\operatorname{RE}(\%)$ & $\mathrm{GR}(\%)$ & $\mathrm{CN}(\%)$ & $\mathrm{RL}(\mathrm{mm})$ & $\mathrm{FW}(\mathrm{g})$ & DW (g) & RGI \\
\hline 0 & $1.48 \mathrm{~b}$ & $4(11) b$ & $82(65) \mathrm{a}$ & $71(57) \mathrm{a}$ & $15.1 \mathrm{a}$ & $2.80 \mathrm{a}$ & 1.05 & $6.62 \mathrm{a}$ \\
\hline 100 & $1.59 \mathrm{~b}$ & $7(15) \mathrm{a}$ & $64(53) \mathrm{b}$ & $42(40) b$ & $4.2 \mathrm{~b}$ & $2.21 \mathrm{~b}$ & 1.12 & $1.77 b$ \\
\hline 200 & $1.97 \mathrm{a}$ & $8(17) \mathrm{a}$ & $14(22) \mathrm{c}$ & $3(11) c$ & $0.4 \mathrm{c}$ & $1.93 \mathrm{bc}$ & 1.11 & $0.18 \mathrm{c}$ \\
\hline 300 & $0 \mathrm{c}$ & $0 \mathrm{c}$ & Od & Od & $0 \mathrm{c}$ & $1.85 \mathrm{c}$ & 1.15 & $0 \mathrm{c}$ \\
\hline$L S D$ & $0.151 * * *$ & $2.084 * * *$ & $2.226 * * *$ & $1.474 * * *$ & $1.201 * * *$ & $0.369 * * *$ & $--^{N S}$ & $0.566 * * *$ \\
\hline \multicolumn{9}{|c|}{$\mathrm{n}-\mathrm{TiO}_{2}\left(\mathrm{mg} \mathrm{L}^{-1}\right)$} \\
\hline 0 & 1.25 & $6(13) \mathrm{a}$ & $41(36) \mathrm{a}$ & 31(29)a & $5.24 a$ & 2.25 & 1.11 & $2.29 a$ \\
\hline 100 & 1.32 & $5(10) \mathrm{b}$ & $42(36) \mathrm{a}$ & $30(28) \mathrm{b}$ & $5.75 \mathrm{a}$ & 2.24 & 1.10 & $2.50 \mathrm{a}$ \\
\hline 200 & 1.21 & $4(10) b$ & $37(33) \mathrm{b}$ & $26(25) \mathrm{c}$ & $3.80 \mathrm{~b}$ & 2.11 & 1.11 & $1.65 \mathrm{~b}$ \\
\hline$L S D$ & $\ldots N S$ & $1.804^{*}$ & $1.928 * *$ & $1.276^{* * *}$ & $0.977 * *$ & $\ldots N S$ & $--^{N S}$ & $0.489 * *$ \\
\hline
\end{tabular}

${ }^{*} \mathrm{p}<0.05, * * \mathrm{p}<0.01, * * * \mathrm{p}<0.001,{ }^{N S}$ : Nonsignificant. Figures in parentheses are arcsine transformed values of percentages.

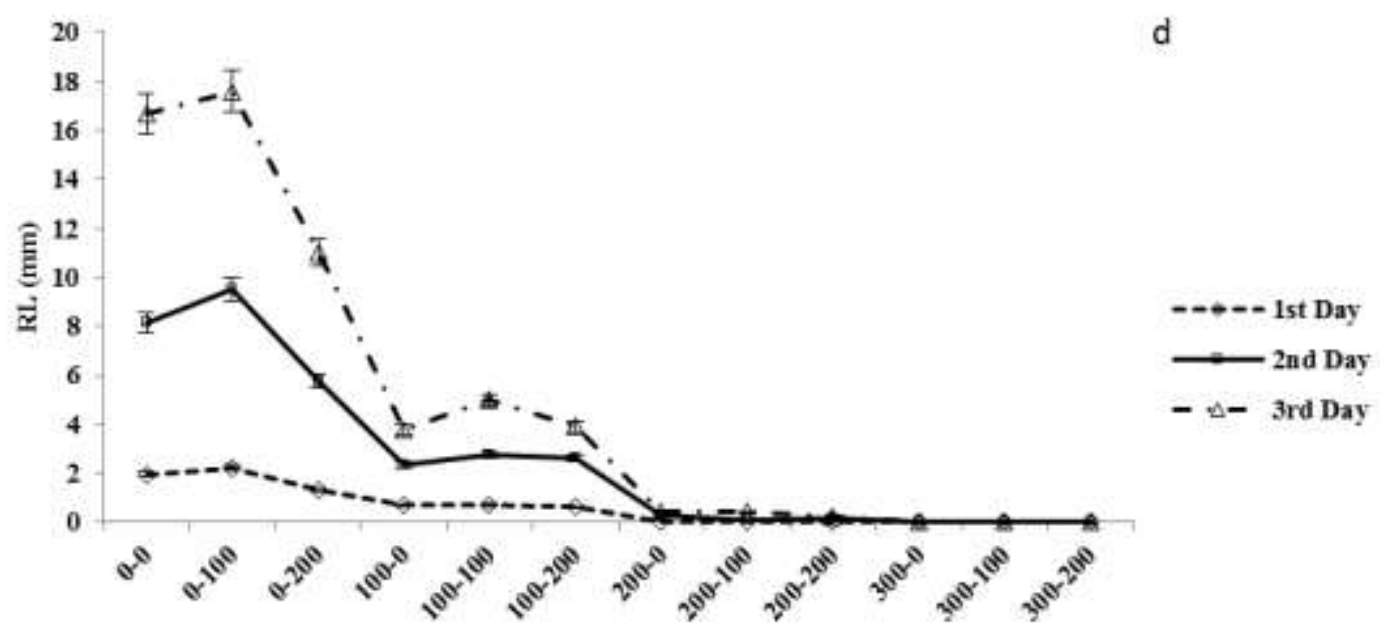

$\mathrm{NaCl}(\mathrm{mM})-\mathrm{TiO}_{2}\left(\mathrm{mgL}^{-1}\right)$

Figure 3. Root length (RL, mm) of barley seedlings in different concentrations of $\mathrm{TiO}_{2} \mathrm{NPs} / \mathrm{NaCl}$ treatments depending on the days.

\section{Conclusion}

This experimental design showed that $\mathrm{n}-\mathrm{TiO}_{2}$ seed priming application at $100 \mathrm{mg} \mathrm{L^{-1 }}$ improved the seedling growth compared to control, and also alleviated the negative effects of salt stress $(100 \mathrm{mM} \mathrm{NaCl})$ by improving growth. The results also show that the effects of nanoparticles may vary depending on concentration. The effects of nanoparticles vary depending on the period of plant development and the duration of application. Therefore, it should be studied in more detail. If the strong clues obtained are supported by observing the advanced development stages of the plants and making field studies, more final results can be reached.

\section{Acknowledgment}

We thank the Dr. Sara Yasemin, Siirt University, for contributions to statistical analyses. We thank the Prof. Dr. Serpil ÜNYAYAR, Faculty of Medicine, Girne American University Drive, TRNC, for supports. 


\section{References}

Acharya P, Jayaprakasha GK, Crosby KM, Jifon JL, Patil BS (2020) Nanoparticle-mediated seed priming improves germination, growth, yield, and quality of watermelons (Citrullus lanatus) at multilocations in Texas. Scientific Reports 10(1): 5037.

Acosta-Motos JR, Ortuño MF, Bernal-Vicente A, Diaz-Vivancos P, Sánchez-Blanco MJ, Hernández JA (2017) Plant responses to salt stress: Adaptive mechanisms. Agronomy 7: 18.

An J, Hu P, Li F, Wu H, Shen Y, White J, Tian X, Li Z, Giraldo JP (2020) Emerging Investigator Series: Molecular mechanisms of plant salinity stress tolerance improvement by seed priming with cerium oxide nanoparticles. Environmental Science: Nano doi: 10.1039/d0en00387e .

Armin M, Asgharipour M, Razavi-Omrani M (2010) The effect of seed priming on germination and seedling growth of watermelon (Citrullus lanatus). Advances in Environmental Biology 4(3): 501505.

Askari H, Kazemitabar SK, Zarrini HN, Saberi MH (2016) Salt tolerance assessment of barley (Hordeum vulgare L.) genotypes at germination stage by tolerance indices. Open Agriculture 1: 37-44.

Ayers AD (1953) Germination and emergence of several varieties of barley in salinized soil cultures. Agronomy Journal 45(2): 68.

Bacilieri FS, Pereira de Vasconcelos AC, Quintao Lana RM, Mageste JG, Torres JLR (2017) Titanium (Ti) in plant nutrition-A review. Australian Journal of Crop Science 11(4): 382-386.

Bağcı SA, Ekiz H, Yılmaz A (2003) Determination of the salt tolerance of some barley genotypes and the characteristics affecting tolerance. Turkish Journal of Agriculture and Forestry 27: 253-260.

Bennett MA, Fritz VA, Callan NW (1992) Impact of seed treatments on crop stand establishment. HortTechnology 2: 345-349.

Dehkourdi EH, Mosavi M (2013) Effect of anatase nanoparticles $\left(\mathrm{TiO}_{2}\right)$ on parsley seed germination (Petroselinum crispum) in vitro. Biological Trace Element Research 155: 283-286.

Demiroğlu Topçu G, Özkan SŞ (2017) Farklı tuz $(\mathrm{NaCl})$ konsantrasyonlarının bazı arpa (Hordeum vulgare L.) çeşitlerinin çimlenme özelliklerine etkisinin belirlenmesi. ÇOMÜ Ziraat Fakültesi Dergisi 5(2): 37-43.

do Espirito Santo Pereira A, Caixeta Oliveira H, Fernandes Fraceto L, Santaella C (2021) Nanotechnology potential in seed priming for sustainable agriculture. Nanomaterials 11(2): 267. doi: 10.3390/nano11020267.

Doğaroğlu Z, Köleli N (2016) Titanyum dioksit ve titanyum dioksitgümüş nanopartiküllerinin marul (Lactuca sativa) tohumunun çimlenmesine etkisi. Çukurova Üniversitesi Mühendislik-Mimarlık Fakültesi Dergisi 31(ÖS2): 193-198. doi: 10.21605/cukurovaummfd.316762.

Feizi H, Razavi P, Shahtahmasebi N, Fotovat A (2012) Impact of bulk and nanosized titanium dioxide $\left(\mathrm{TiO}_{2}\right)$ on wheat seed germination and seedling growth. Biological Trace Element Research 146: 101106.

Gao Y, Cui Y, Long R, Sun Y, Zhang T, Yang Q, Kang J (2018) Saltstress induced proteomic changes of two contrasting alfalfa cultivars during germination stage. Journal of Science of Food and Agriculture 99(3): 1384-1396.

Garcia-Lopez JS, Lira-Saldivar RH, Zavala-Garcia F, Olivares-Saenz E, Nino-Medina G, Ruiz-Torres NA, Mendez-Arguello B, DiazBarriga E (2018) Effects of zinc oxide nanoparticles on growth and antioxidant enzymes of Capsicum chinense. Toxicological\&Environmental Chemistry 100: 560-572 ISSN: 0277-2248.

Gogos A, Knauer K, Bucheli TD (2012) Nanomaterials in plant protection and fertilization: current state, foreseen applications, and research priorities. Journal of Agricultural and Food Chemistry 60(39): 9781-9792.
Gohari G, Mohammadi A, Akbari A, Panahirad S, Dadpour MR, Fotopoulos V, Kimura S (2020) Titanium dioxide nanoparticles $\left(\mathrm{TiO}_{2} \mathrm{NPs}\right)$ promote growth and ameliorate salinity stress effects on essential oil profile and biochemical attributes of Dracocephalum moldavica. Scientific Reports 10(1): 912.

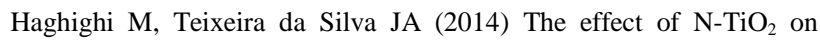
tomato, onion, and radish seed germination. Journal of Crop Science and Biotechnology 17(4): 221-227.

Katerji N, Hoorn JW, Hamdy A, Mastrorilli M, Fares C, Ceccarelli S, Grando S, Oweis T (2006) Classification and salt tolerance analysis of barley varieties. Agricultural Water Management 851(1-2): 184192.

Kaya MD, Okçu G, Atak M, Çıkılı Y, Kolsarıcı Ö (2006) Seed treatments to overcome salt and drought stress during germination in sunflower (Helianthus annuus L.). European Journal of Agronomy 24: 291-295.

Koksal N, Agar A, Yasemin S (2015) The effects of top coat substrates on seedling growth of marigold. Journal of Applied Biological Sciences 9(3): 66-72.

Korkmaz A, Pill WG (2003) The effect of different priming treatments and storage conditions on germination performance of lettuce seeds. European Journal of Horticultural Science 68(6): 260-265.

Liu HH, Cohen Y (2014) Multimedia environmental distribution of engineered nanomaterials. Environmental Science \& Technology 48(6): 3281-3292.

Lutts S, Benincasa P, Wojtyla L, Szymon Kubala S, Pace R, Lechowska K, Quinet M, Garnczarska M (2016) Seed priming: new comprehensive approaches for an old empirical technique. New Challenges in Seed Biology - Basic and Translational Research Driving Seed Technology. Intechopen.

Lyu S, Wei X, Chen J, Wang C, Wang X, Pan D (2017) Titanium as a beneficial element for crop production. Frontiers in Plant Science 8: 597.

Macwan DP, Dave PN, Chaturvedi S (2011) A review on nano-TiO sol-gel type syntheses and its applications. Journal of Materials Science 46(11): 3669-3686.

Mahakham W, Sarmah AK, Maensiri S, Theerakulpisut P (2017) Nanopriming technology for enhancing germination and starch metabolism of aged rice seeds using phytosynthesized silver nanoparticles. Scientific Reports 7(1): 8263.

Mahdy AM, Sherif FF, Elkhatib EA, Fathi NO, Ahmed MH (2020) Seed priming in nanoparticles of water treatment residual can increase the germination and growth of cucumber seedling under salinity stress. Journal of Plant Nutrition 43(12): 1862-1874. doi: 10.1080/01904167.2020.1750647.

Mahmood K (2011) Salinity tolerance in barley (Hordeum vulgare L.): Effects of varying $\mathrm{NaCl}, \mathrm{K}^{+} / \mathrm{Na}^{+}$and $\mathrm{NaHCO}_{3}$ levels on cultivars differing in tolerance. Pakistan Journal of Botany 43: 1651-1654.

Mutlu F, Yürekli F, Mutlu B, Emre FB, Okusluk F, Ozgul O (2018) Assessment of phytotoxic and genotoxic effects of anatase $\mathrm{TiO}_{2}$ nanoparticles on maize cultivar by using rapd analysis. Fresenius Environmental Bulletin 27(1): 436-445.

OECD (2010). List of manufactured nanomaterials and list of endpoints for phase one of the sponsorship programme for the testing of manufactured nanomaterials: Revision. safety of manufactured nanomaterials.

Panuccio MR, Jacobsen SE, Akhtar SS, Muscolo A. (2014) Effect of saline water on seed germination and early seedling growth of the halophyte quinoa. AoB Plants 6:047, doi: 10.1093/aobpla/plu047.

Piccinno F, Gottschalk F, Seeger S, Nowack B (2012) Industrial production quantities and uses of ten engineered nanomaterials in Europe and the world. Journal of Nanoparticle Research 14(9): 1109. 
Ren J, Sun LN, Zhang QY, Song XS (2016) Drought tolerance is correlated with the activity of antioxidant enzymes in Cerasus humilis seedlings. Biomed Research International 7: 1-9.

Theerakulpisut P, Kanawapee N, Panwong B (2016) Seed priming alleviated salt stress effects on rice seedlings by improving $\mathrm{Na}+/ \mathrm{K}+$ and maintaining membrane integrity. International Journal of Plant Biology 7(6402): 53-58.
Younes NA, Shokry Hassan H, Elkady MF, Hamed AM, Dawood MFA (2020) Impact of synthesized metal oxide nanomaterials on seedlings production of three Solanaceae crops. Heliyon 6(1): E03188. doi: 10.1016/j.heliyon.2020.e03188. 